\title{
(j)
}

AL-DZIKRA

Jurnal Studi Ilmu Al-Qur'an Dan Al-Hadits

http://ejournal.radenintan.ac.id/index.php/al-dzikra

Volume 12, No. 2, Desember Tahun 2018, Halaman 165 - 188

DOI://dx.doi.org/10.24042/al-dzikra.v12i2.2079

\section{HADITS NABI SAW TENTANG OBAT DALAM TINJAUAN ILMU KEDOKTERAN MODERN}

\author{
Alfandi Ilham Safarsyah \\ Fakultas Ushuluddin dan pemikiran Islam \\ UIN Sunan Kalijaga Yogyakarta \\ Junitaindriastuti@gmail.com
}

\section{Abstrak}

Telah majunya tekhnologi mendorong umat Islam untuk melakukan pembaharuan dalam kajian terhadap hadis. Nabi $S A W$ telah memberikan contoh obat-obatan yang memiliki banyak manfaat. Diantaranya habbatus sauda', zaitun dan madu. Dalam ilmu kedokteran modern telah banyak ditemukan manfaat dan zat-zat yang terkandung di dalamnya. Hal ini mampu menguatkan hadis Nabi $S A W$ dimana hadis itu muncul jauh sebelum majunya ilmu kedokteran dan tekhnologi. Kajian ini diperuntukkan agar pemahaman terhadap hadis mampu bersifat komprehensif dalam segala aspek, sehingga menguatkan kebenaran hadis. Dalam kajian ini juga dapat dilihat perbedaan pemahaman tentang hadis tersebut dari ulama terdahulu dengan ulama kontemporer, terdapat faktor yang mempengaruhi pemahaman hadis salah satunya yaitu faktor kemajuan IPTEK. Semakin majunya ilmu dan tekhnologi ini mendorong umat muslim untuk mengkaji hadis dengan pendekatan sains, yaitu dengan penelitian, sehingga ditemukanlah beberapa manfaat yang terkandung di dalam habbatus sauda', zaitun dan madu mulai dari menyembuhkan penyakit dalam seperti sesak nafas, 
penyakit kuning, menurunkan kolesterol, selain itu juga dalam hal kecantikan mampu memperindah kulit bahkan sebagai bahan makanan.

Kata Kunci: Habbatus sauda', Zaitun, Madu, Kedokteran Modern.

\section{A. Pendahuluan}

Kajian terhadap hadis sudah sangat banyak dilakukan oleh para ulama baik ulama salaf maupun ulama kontemporer. Telah banyak buku-buku dan jurnal yang menulis tentang ilmu hadis dan kajian-kajian hadis dengan berbagai variasinya. Kita ketahui bahwa awal pembukuan hadis ialah pada masa khalifah Umar bin Abdul Aziz tepatnya pada tahun $100 \mathrm{H}^{1}$ Mulai sejak itu berkembanglah ilmu hadis sampai saat ini. Banyak kajian-kajian tentang hadis yang membahas masalah ibadah, aqidah dan mu'amalah. Akan tetapi masih belum banyak ahli-ahli hadis yang mengkaji hadis yang berbicara mengenai kealaman.

Banyak hadis-hadis Nabi SAW yang berbicara tentang kealaman, diantaranya berbicara mengenai bintang, embriologi, gerhana, berkumur, bersin, madu, kurma, zaitun, habbatus sauda' dan lain-lain. Yang mana hadis-hadis tersebut membutuhkan pendekatan keilmuwan dalam membuktikan kebenarannya. Perlu adanya penelitian dan percobaan (tajribiyyah) dalam membuktikan hadis -hadis Nabi SAW yang mengandung isyarat ilmiah tersebut. Sebenarnya dasar-dasar metode pengamatan untuk mendapatkan pengetahuan merupakan arahan al-Qur'an, dimana pengamatan dengan penglihatan dan pendengaran yang merupakan alat untuk dapat memberikan input pada pikiran banyak dianjurkan oleh al-Qur'an, misalnya dalam surat An-Nahl ayat 78. Demikian menurut Dr. Muhammad al-Syarqawiy bahwa al-Qur'an mendorong umat muslim untuk melakukan pengamatan bahkan percobaan serta penelitian. ${ }^{2}$

Dengan demikian umat muslim perlu mengkaji lebih banyak lagi mengenai ayat ataupun hadis yang berbicara soal kealaman. Dalam kajian ini berfokus kepada hadis Nabi SAW

1 T.M Hasbi ash-Shiddieqy, Sejarah dan Pengantar Ilmu Hadis, (Semarang: Pustaka Rizki Putra, 2009), hlm.52.

${ }^{2}$ Asjmuni Abdurrahman, manhaj Tarjih muhammadiyah, (Yogyakarta: Pustaka Pelajar, 2012), hlm 297-298. 
yang berbicara mengenai obat-obatan. Ada tiga hadis utama yang menjadi fokus yaitu hadis mengenai habbatus sauda', zaitun dan madu. Nabi SAW telah memberikan kabar kepada umatnya bahwa terkandung beberapa manfaat yang terdapat di dalamnya. Akan tetapi perlu penelitian dengan menggunakan pendekatan ilmu kedokteran, yang mana saat ini tekhnologi sudah sangatlah maju sehingga mendukung akan pengkajian hadis dengan metode penelitian.

Dalam hal ini akan dipaparkan penjelasan dari ulama salaf hingga ulama kontemporer tentang hadis tersebut. Selain itu ada juga hasil dari penelitian mengenai kandungan dan zat-zat yang terdapat di dalam habbatus sauda', zaitun dan madu. Kajian ini sebagai penguat kebenaran bukan bermaksud meragukan kebenaran hadis Nabi SAW. Hal ini juga sebagai motivasi umat muslim untuk lebih berinovasi dan mengembangkan keilmuwan sehingga mampu menjadi umat yang kreatif, dinamis dan berkemajuan.

\section{B. Habbatus sauda'(Black Cumin)}

1. Hadis Mengenai Habbatus sauda' dan Takhrijnya

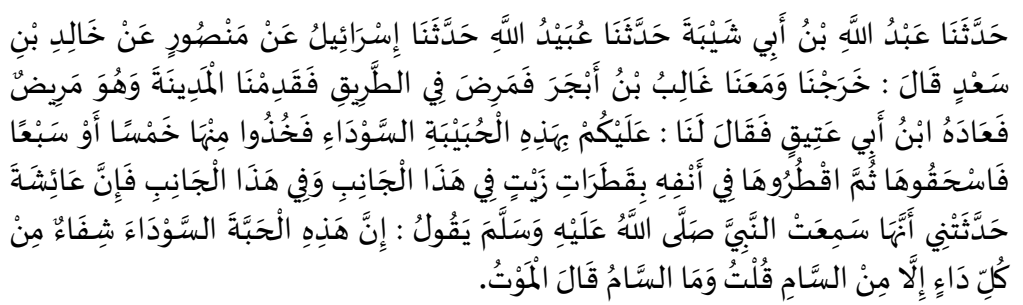

Artinya: "Telah menceritakan kepada kami Abdullah bin Abu Syaibah telah menceritakan kepada kami 'Ubaidullah telah menceritakan kepada kami Israil dari Manshur dari Khalid bin Sa'd dia berkata; Kami pernah bepergian yang di antaranya terdapat Ghalib bin Abjar, di tengah jalan ia jatuh sakit, ketika sampai di Madinah ia masih menderita sakit, lalu Ibnu Abu 'Atiq menjenguknya dan berkata kepada kami; "Hendaknya kalian memberinya habbatus sauda' (jintan hitam), ambillah lima atau tujuh biji, lalu tumbuklah hingga halus, setelah itu teteskanlah di hidungnya di sertai dengan tetesan minyak sebelah sini dan sebelah 
sini, karena sesungguhnya Aisyah pernah menceritakan kepadaku bahwa dia mendengar Nabi shallallahu 'alaihi wasallam bersabda: "Sesungguhnya habbatus sauda' ini adalah obat dari segala macam penyakit kecuali saam." Aku bertanya; "Apakah saam itu?" beliau menjawab: "Kematian."(HR. Bukhari: 5255). ${ }^{3}$

Hadis diatas merupakan hadis utama yang menjadi dasar kajian bahwasanya habbatus sauda' merupakan obat dari berbagai penyakit. Hadis ini merupakan hadis yang diriwayatkan oleh Abdullah bin Muhammad bin Abi Syaibah Ibrahim bin 'Utsman yang berasal dari kalangan Tabi'ul Atba' yang semasa hidup berdomisili di Kufah, dan wafat tahun $235 \mathrm{H}$. Menurut Imam Ahmad bin Hambal ia digelari Shaduq, dan menurut Imam Ibnu Hatim, ia diberi gelar Tsiqah. ${ }^{4}$

Hadis ini ditakhrij dengan bantuan aplikasi Lidwa Pustaka, yang ditemukan dalam Kitab Shahih Bukhari No. 5255 menggunakan metode pencarian dengan kata kunci "habbatussauda". Selain pada kitab Shahih Bukhari, hadis ini juga terdapat dalam:

\begin{tabular}{|l|l|l|}
\hline \multicolumn{1}{|c|}{ Nama Kitab } & \multicolumn{1}{c|}{ Periwayat } & \multicolumn{1}{c|}{ Nomor Hadis } \\
\hline Shahih Bukhari & Aisyah & 5255 \\
\hline Shahih Muslim & Abu Hurairah & 4105 \\
\hline Sunan at-Tirmidzi & Abu Hurairah & 1964 \\
\hline Sunan Ibnu Majah & Aisyah & 3440 \\
\hline Musnad Ahmad & Abu Hurairah & 6986 \\
\hline
\end{tabular}

Disamping itu, terdapat hadis dari riwayat lain yang berbicara mengenai habbatus sauda'. Diantaranya:

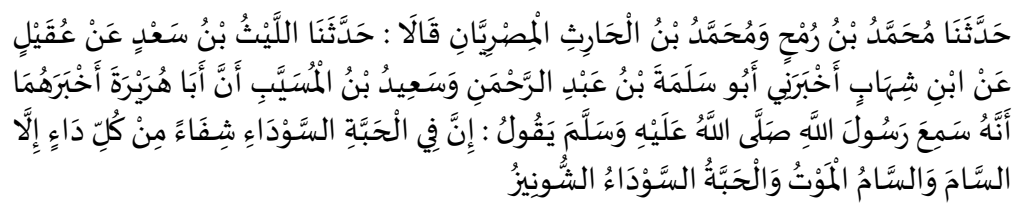


Artinya : "Telah menceritakan kepada kami Muhammad bin Rumh dan Muhammad bin Al Harits Al Mushriyan keduanya berkata; telah menceritakan kepada kami Al Laits bin Sa'd dari 'Uqail dari Ibnu Syihab telah mengabarkan kepadaku Abu Salamah bin Abdurrahman dan Sa'id bin Al Musayyab bahwa Abu Hurairah mengabarkan kepada keduanya, bahwa dia mendengar Rasulullah shallallahu 'alaihi wasallam bersabda: "Sesungguhnya dalam habbatus sauda' (jintan hitam) terdapat obat dari segala jenis penyakit kecuali as saam, dan as saam adalah kematian, dan habbatus sauda' adalah Asy syuniz." (HR. Ibnu Majah - 3438)

Hadis ini terdapat dalam ${ }^{6}$ :

\begin{tabular}{|c|c|}
\hline Sunan Imam Ahmad & 12 Hadis \\
\hline Shahih Bukhari & 1 Hadis \\
\hline Sunan Ibnu Majah & 3 Hadis \\
\hline Shahih Muslim & 2 Hadis \\
\hline Sunan Tirmidzi & 1 Hadis \\
\hline TOTAL & 19 Hadis \\
\hline
\end{tabular}

Mufradat ${ }^{7}$ :

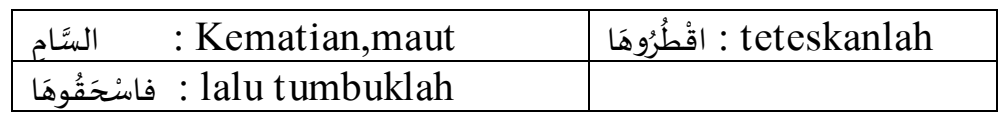

2. Kandungan Hadis secara Global

Perlu dikemukakan bahwa hadis Nabi SAW tentang habbatus sauda' pada dasarnya memberikan informasi dan menganjurkan bahwa habbatus sauda' sebagai salah satu obat yang bersifat umum dan memiliki manfaat besar bagi kesehatan. Hadis tersebut bukan bermakna hanya habbatus sauda' yang dapat menyembuhkan segala penyakit. Boleh jadi, penyakit pada masa

${ }^{5}$ CD Lidwa Ensiklopedi Hadis 9 Imam

${ }^{6}$ CD Lidwa Ensiklopedi Hadis 9 Imam

7 Ahmad Warson Munawir. Kamus Al-Munawwir Arab-Indonesia. (Yogyakarta: Pustaka Progresif,1997) hlm. 663, 1132, 616. 
itu belum banyak, tidak kompleks dan bersifat ringan, sehingga Nabi SAW memberikan informasi untuk konteks zamannya yang bersifat preventif dengan menganjurkan mengkonsumsi habbatus sauda' untuk memperkuat sistem kekebalan tubuh. ${ }^{8}$

Ibnu Qayyim menjelaskan, “habbatus sauda' atau syuniz dalam bahasa Persia atau cumin hitam, oleh Hasan dijelaskan seperti yang diriwayatkan dari al-Harbi, 'Ia (habbatus sauda') adalah lada'." Al-Harwi meriwayatkan," Ia (habbatus sauda') adalah biji hijau buah Buthm." Keduanya salah, yang benar habbatus sauda' adalah syuniz.

Apa maksud sabda Nabi SAW "Obat segala penyakit" apakah kalimat tersebut bersifat umum ataukah khusus, ada dua pendapat yaitu:

Pertama, bersifat khusus. Al-Khaththabi menjelaskan "Kata-kata ini termasuk kata umum namun dimaksudkan khusus. Tidak ada satupun jenis tanaman atau pohon yang menyatukan berbagai fungsi obat untuk mengobati berbagai penyakit dengan berbagai jenis dan spesifikasinya. Yang dimaksud obat dalam hadis tersebut adalah obat untuk penyakit yang timbul karena kelembaban, udara dingin dan lendir, karena karakter habbatus sauda' adalah kering.

Abu Bakar bin al-Arabi menjelaskan "Madu bagi para dokter lebih sebagai obat segala penyakit melebihi habbatus sauda'. Meski demikian ada sebagian penyakit tertentu yang jika si penderita diberi madu malah justru akan terganggu. Jika yang dimaksud 'didalamnya terdapat obat untuk manusia', pada madu biasanya diartikan seperti itu, berarti habbatus sauda' lebih utama untuk diartikan seperti itu. Al-Maunawi menjelaskan, "obat segala penyakit" yaitu penyakit yang disebabkan oleh kelembaban. Sebab, tidak ada tanaman yang memiliki fungsi obat untuk semua penyakit.

Kedua, bersifat umum. Abu Muhammad bin Abu Jamrah menjelaskan, "Para ahli membahas hadis ini, mereka mengkhususkan keumumannya, dan mereka merujukkan ke penjelasan pakar pengobatan dan yang sudah berpengalaman. Pandangan seperti ini jelas keliru, sebab jika kita mempercayai

\footnotetext{
${ }^{8}$ Nizar Ali, Hadis Versus Sains, (Yogyakarta: Teras, 2008), hlm.29.
} 
perkataan ahli pengobatan yang pengetahuan mereka pada umumnya didasarkan pada eksperimen, sementara eksperimen itu bertumpu pada diagnosis. Maka kita harus lebih percaya dan menerima perkataan Rasul SAW yang tidak berbicara berdasarkan hawa nafsu.

\section{Pandangan Ulama mengenai Hadis}

Al-Mubarakfuri menjelaskan, "Menurut salah satu pendapat, sabda ini tetap berlaku secara umum. Tanggapan pernyataan al-Khaththabi bahwa tidak ada satupun tanaman yang memiliki fungsi seluruh obat, orang bilang: tidaklah mustahil bagi Allah menyatukan seluruh alam dalam satu wujud manusia".

Adapun Ibnu Hajar menjelaskan, bahwa bisa disimpulkan makna "habbatus sauda' sebagai obat segala penyakit" adalah habbatus sauda' tidak digunakan untuk mengobati berbagai penyakit begitu saja, kadang digunakan secara mandiri, kadang dicampur dengan unsur lain, kadang ditumbuk, tidak ditumbuk, dimakan, diminum, dioleskan, dan lainnya. Beliau juga menjelaskan berdasarkan penjelasan sebelumnya, pandangan yang mengartikan umum lebih tepat, dengan catatan, bahwa yang dimaksud lebih umum dari penggunaan habbatus sauda' secara tersendiri maupun dicampur dengan unsur lain". ${ }^{9}$

Adapun pendapat dari ulama modern yaitu pendapat dari Dr. Ahmad al-Qadhi, sebagaimana dikutip oleh Zaghlul an-Najar, setelah dia meneliti dan mengamati secara intens dan cermat terhadap habbatus sauda' dalam perspektif kedokteran dengan melihat hadis tersebut, dia berkata bahwa "Hadis tentang habbatus sauda' penyembuh segala penyakit kecuali kematian, harus dipahami kaitannya dengan sistem kekebalan dalam tubuh manusia yang telah dikaruniakan oleh Allah untuk memproteksi tubuhnya". Dia melakukan studi hubungan habbatus sauda' dengan sistem imunitas terhadap sejumlah orang yang terkena penyakit penurunan imunitas tubuh. ${ }^{10}$

${ }^{9}$ Abdullah Umar Bamusa dan Yusuf Abu al-Hujaj, Sembuh Dan Sehat Dengan Habbatus sauda', Terj. Umar Mujtahid (Solo: Aqwamedia, 2011), hlm.20-25.

${ }^{10}$ Nizar Ali, Hadis Versus Sains, (Yogyakarta: Teras, 2008), hlm.25. 


\section{Habbatus sauda'Dalam Pengobatan Modern}

Habbatus sauda' adalah biji buah dari tanaman sejenis rumput, seperti jinten (Indonesia) berwarna hitam pekat yang banyak dijumpai didaerah pinggiran Mediterranean Sea. Tumbuhan yang ditanam di banyak negara ini dikenal dalam ilmu Biologi dengan nama "Nigella Sativa". Di Mesir dikenal dengan nama "Habbah al-Barakah", dan di Syiria dikenal dengan nama "al-Qaz'ah", serta di Yaman disebut dengan istilah "Qahthah". Sementara di Persia dinamakan "Syuniz". Percobaan modern terhadap manusia dan hewan telah membuktikan bahwa habbatus sauda' mempunyai efek melawan mikroba, mengatur tekanan darah dan mengatasi penyakit asma. ${ }^{11}$

Riset yang dilakukan oleh seorang ilmuan bernama Crones pada tahun 1880 tentang komposisi habbatus sauda' tergolong riset pertama dibidang ini. Riset ini menyimpulkan, biji ini memiliki kandungan $27 \%$ air, 4,14\% abu dengan kandungan unsur kalsium utama. Setelah itu barulah muncul berbagai riset mengenai habbatus sauda'.

Komposisi Utama Habbatus sauda':

\begin{tabular}{|l|l|}
\hline \multicolumn{1}{|c|}{ Nama Bagian } & Prosentase Per-Berat Habbatus sauda' \\
\hline Fixed Oil & $32-40 \%$ \\
\hline Volatile Oil & $0,4-0,45 \%$ \\
\hline Protein & $16-19,9 \%$ \\
\hline Tunas & $33,9 \%$ \\
\hline Serat & $4,5-6,5 \%$ \\
\hline Air & $5,1-7 \%$ \\
\hline Abu & $3,7-7 \%$ \\
\hline
\end{tabular}

Tabel diatas menjelaskan kadar komposisi yang ada berbanding berat biji habbatus sauda'. Meski habbatus sauda' memiliki komposisi dalam jumlah yang kecil dan parsial, namun memiliki nilai penting dalam pengobatan. Sebab komposisi yang terkandung memiliki efek terhadap fungsi organ tubuh, mengatasi penyakit, dan efek terhadap sumber-sumber penyakit, seperti kandungan alkaloids coumarines.

\footnotetext{
${ }^{11}$ Nizar Ali, Hadis Versus Sains, (Yogyakarta: Teras, 2008), hlm.24.
} 
Fixed oil dalam habbatus sauda' mengandung zat asam, minyak dan sterol. Sementara volatile oil-nya mengandung unsur nigellon. Peneliti pertama yang berhasil memisahkan unsur ini adalah Mahfudz dan Dukhkhani pada tahun 1960. Selanjutnya Dukhkhani dapat mencapai kesimpulan bahwa fixed oil dalam habbatus sauda' memiliki unsur timokinon yang dinilai sebagai unsur pengobatan yang efektif pada tanaman ini.

Penelitian yang paling menyita perhatian adalah riset $\mathrm{Abu}$ Thabl dan para mahasiswanya pada tahun 1986 yang berhasil mengungkap 67 unsur dalam volatile oil habbatus sauda', namun tidak lebih dari $0,4 \%$ berat total habbatus sauda'. Artinya jika mengambil 1 gram habbatus sauda' hanya ada 0,004 gram fixed oil, yaitu setara 4 mikrogram. Namun dalam kandungan minyak sekecil itu terdapat 67 unsur kimia. ${ }^{12}$

Adapun unsur dan komposisi aktif didalam habbatus sauda' yaitu mengandung minyak asiri dengan prosentase 0,8 $1,1 \%$ pada jenis habbatus sauda' yang banyak beredar, dan 0,6$0,9 \%$ pada jenis damascena. Habbatus sauda' juga mengandung banyak sekali unsur dan zat aktif dengan manfaat yang besar dan luar biasa. Diantara unsur utamanya adalah phospat, zat besi, phospor, karbohidrat, nigellon, chabonezat, dan tannin.

Selanjutnya unsur kimiawi yang terkandung didalam habbatus sauda', dalam 100 gram habbatus sauda' mengandung zat-zat sebagai berikut: ${ }^{13}$

\begin{tabular}{ll}
\hline \multicolumn{1}{c}{ Zat } & Kandungan dalam 100 gram \\
\hline Air & 13,19 gram \\
Protein & 9,17 gram \\
Lemak & 9,12 gram \\
Kalsium & $80,10 \mathrm{mg}$ \\
Vitamin A & $20 \mathrm{mg}$ \\
Niasin & $6,2 \mathrm{mg}$ \\
\hline
\end{tabular}

12 Abdullah Umar Bamusa dan Yusuf Abu al-Hujaj, Sembuh Dan Sehat Dengan Habbatus sauda', Terj. Umar Mujtahid (Solo: Aqwamedia, 2011), hlm. 37-38.

${ }^{13}$ Abdullah Umar Bamusa dan Yusuf Abu al-Hujaj, Sembuh Dan Sehat Dengan Habbatus sauda', Terj. Umar Mujtahid (Solo: Aqwamedia, 2011), hlm. 39. 


\begin{tabular}{ll}
\hline Fiber & $3,6 \mathrm{mg}$ \\
$\mathrm{Abu}$ & $8,7 \mathrm{mg}$ \\
Kalori & 463 \\
\hline
\end{tabular}

\section{Manfaat Pengobatan Habbatus sauda'}

Dawud al-Anthaki menunjukkan sejumlah manfaat pengobatan dari habbatus sauda' ini. Ia mengatakan "Habbatus sauda' bisa menyembuhkan perut kembung, menghilangkan penyakit kembung, nyeri dada, batuk, sesak nafas, mual, edema (busung air), asites, sakit kuning, dan penyakit pada limpa”. Dawud al-Anthaki menegaskan jika habbatus sauda' dicampur minyak maka ia bisa memerahkan dan menjernihkan warna kulit, menghancurkan batu ginjal, dan memperlancar air seni. Adapun menghirup uap habbatus sauda' bisa menyembuhkan pening, demam, dan influenza. Habbatus sauda' dicampur cuka dan madu bisa menyembuhkan berbagai luka. Meminum minyak habbatus sauda' dicampur dengan getah pohon akan mengembalikan nafsu syahwat setelah melemah.

Biji-bijian habbatus sauda' mengandung zat-zat antibodi yang mampu membunuh berbagai virus, mikroba, dan bakteri. Habbatus sauda' juga mengandung zat-zat karotenoid sebagai zat anti kanker. Ia juga mengandung hormon-hormon seks yang berfungsi memperkuat, mempersubur dan memperaktif serta mengandung zat-zat pelancar air seni, haid, air susu ibu, dan empedu. Ia juga mengandung enzim-enzim pencerna dan zat anti asam, disamping zat-zat aktif dan penenang secara bersamaan.

Pada masa sekarang unsur nigellon dapat dipisahkan dari minyak asiri habbatus sauda' dan digunakan sebagai obat reaksi cepat untuk penyakit asma, serangan-serangan akut karena pengaruh dinginnya udara, juga untuk mengobati batuk membandel. Unsur thymohydroquinone juga berhasil dipisahkan dari minyak asiri habbatus sauda'. Zat ini digunakan sebagai zat anti bakteri usus sebagai unsur pembersih flora lambung yang berbahaya. Para ilmuan yakin, dengan penelitian-penelitian yang terus dilakukan dengan dukungan perangkat-perangkat ilmuah 
modern, mereka akan semakin mengungkap banyak rahasia pengobatan dengan habbatus sauda' ${ }^{14}$

\section{Buah Zaitun}

1. Hadis tentang Buah Zaitun dan Takhrijnya

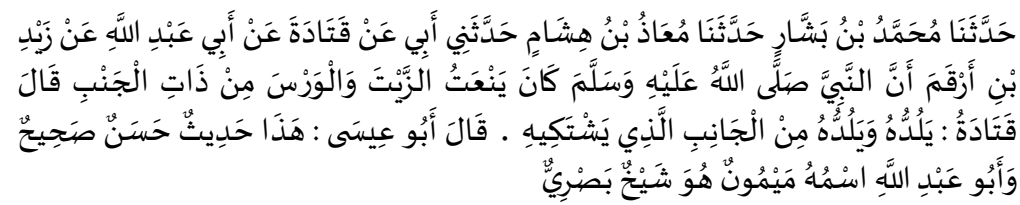

"Telah menceritakan kepada kami Muhammad bin Basysyar; telah menceritakan kepada kami Mu'adz bin Hisyam; telah menceritakan kepadaku bapakku dari Qatadah dari Abu 'Abdullah dari Zaid bin Arqam bahwasanya Nabi shallallahu 'alaihi wasallam biasanya menjelaskan tentang (khasiat) minyak zaitun dan wars bagi orang yang menderita radang selaput dada. Qatadah berkata, "Meminumnya, yakni meminum dan mengarahkannya pada salah satu sisi mulut (kanan atau kiri) sesuai dengan bagian yang terasa sakit." Abu Isa berkata; Ini adalah hadits hasan shahih. Dan Abu Abdullah namanya adalah Maimun dan seorang Syaikh Bashri (HR. Tirmidzi: 2004) $)^{15}$

Hadis ini ditakhrij dengan bantuan aplikasi Lidwa Pustaka, yang ditemukan dalam Sunan at-Tirmidzi dan Sunan Ahmad nomor 3458 kitab at-Thibb dan menggunakan metode pencarian dengan kata kunci "الزيت".

Selain itu, terdapat hadis yang hampir serupa pada Sunan Tirmidzi dan Sunan Ahmad dengan periwayatan dari Raja' bin Muhammad Al 'Udzri Al Bashri, dari 'Amr bin Muhammad bin Abu Razin dari Syu'bah dari Khalid Al Hadzdza' dari Maimun Abu 'Abdullah mendengar dari Zaid bin Arqam dari Abu Isa. Dan redaksi berbeda pada bagian "Rasulullah shallallahu 'alaihi wasallam memerintahkan kepada kami agar berobat dengan

${ }^{14}$ Abdullah Umar Bamusa dan Yusuf Abu al-Hujaj, Sembuh Dan Sehat Dengan Habbatus sauda', Terj. Umar Mujtahid (Solo: Aqwamedia, 2011), hlm. 64-66.

${ }^{15}$ CD Lidwa Ensiklopedi Hadis 9 Imam 
menggunakan al-qusth al-bahri dan minyak Zaitun jika menderita radang selaput dada" Salah satu pendapat mengatakan bahwa dzatul janb disini memiliki makna "batuk", dan disebutkan dalam periwayatan tersebut bahwasanya hadits ini adalah hadis Hasan Gharib. ${ }^{16}$

Disamping hadis utama, terdapat hadis lain yang berhubungan dengan buah Zaitun, yaitu:

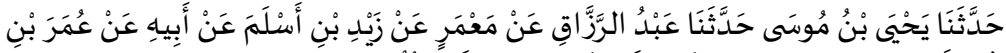

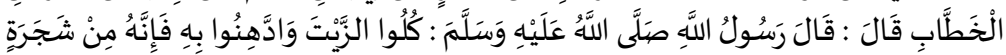

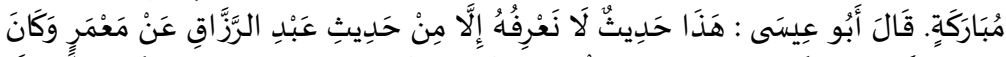

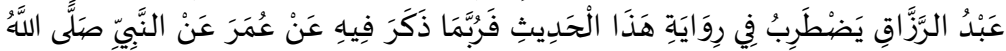

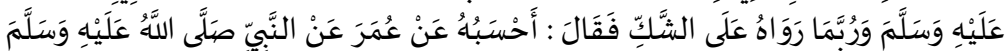

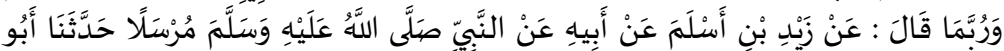

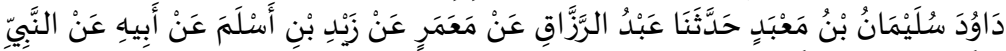

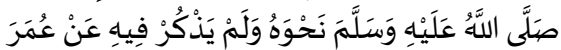

Artinya: "Telah menceritakan kepada kami Yahya bin Musa, telah menceritakan kepada kami Abdurrazzaq dari Ma'mar dari Zaid bin Aslam dari bapaknya dari Umar bin Al Khaththab ia berkata; Rasulullah shallallahu 'alaihi wasallam bersabda: "Makanlah minyak zaitun dan berminyaklah dengannya (pergunakan untuk selain makan), karena dia dihasilkan dari pohon yang diberkahi." Berkata Abu 'Isa: Ini merupakan hadits yang tidak kami ketahui kecuali dari haditsnya Abdurrazzaq dari Ma'mar, dan Abdurrazzaq mengalami Idlthirab dalam meriwayatkan hadis ini, terkadang dia menyebutkan dari Umar dari Nabi shallallahu 'alaihi wasallam dan terkadang meriwayatkannya dengan ragu-ragu dengan berkata, "Pekiraan saya, diriwayatkan dari Umar dari Nabi shallallahu 'alaihi wasallam." Atau ia berkata: "Dari Zaid bin Aslam dari bapaknya dari Nabi shallallahu 'alaihi wasallam secara mursal. Telah menceritakan kepada kami Abu Dawud Sulaiman bin Ma'bad, telah menceritakan kepada kami Abdurrazzaq dari Ma'mar dari Zaid bin Aslam dari bapaknya dari Nabi shallallahu 'alaihi wasallam semisalnya, namun di dalam sanadnya ia tidak menyebutkan; Dari Umar. (HR. Tirmidzi). ${ }^{17}$

\footnotetext{
${ }^{16}$ CD Mausu'uatul Hadits an-Nabawiyah

${ }^{17}$ CD Lidwa Ensiklopedi 9 Imam
} 
Hadis ini juga terdapat dalam sunan ad-Darimi di kitab alAth'imah nomor 1963. ${ }^{18}$

Mufradat $^{19}$

\begin{tabular}{|c|c|}
\hline ينْعَتُ : menjelaskan ( menyifati) & : يَلُدُه : meminumnya \\
\hline يَتَشْتَكِيهِ :yang sakit & ا ادَّهِنُوا : oleskan \\
\hline الْوَرس : jenis tumbuh-tumbuhan & \\
\hline
\end{tabular}

2. Kandungan Hadis secara Global

Zaitun (sebagai buah) dan minyak zaitun telah disebutkan dalam al-Qur'an sebanyak tujuh kali. ${ }^{20}$ Allah pernah bersumpah dengan menggunakan media zaitun pada salah satu surat di alQur'an. Allah juga mengisyaratkan pohon zaitun dengan isyarat yang tidak terdefinisikan:

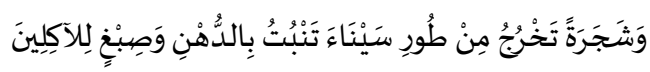

Artinya: "Dan pohon kayu ke luar dari Thursina ( pohon zaitun) yang menghasilkan minyak, dan pewarna makanan (lauk) bagi orang-oramg yang makan.” (QS. Al-Mu'minun: 20)

Klausa "menghasilkan minyak", mendeskripsikan bahwa pohon yang dimaksud adalah pohon zaitun. Sedangkan kata pewarna, merupakan arti dari lauk. Ayat ini sesuai dengan hadis yang kedua di pembahsan sebelumnya. ${ }^{21}$

Kedua hadis tentang zaitun ini, menjelaskan bahwasanya buah zaitun itu memiliki khasiat dan manfaat diantaranya adalah obat batuk, dan juga bisa dijadikan sebagai lauk atau bahan masakan. Buah ini juga merupakan buah dari pohon yang diberkahi. Zaitun memiliki banyak manfaat selain yang telah disebutkan, diantaranya akan disebutkan pada pembahasan selanjutnya.

${ }^{18}$ CD Mausu'uatul Hadits an-Nabawiyah

19 Ahmad Warson Munawir. Kamus Al-Munawwir Arab-Indonesia. (Yogyakarta: Pustaka Progresif,1997) hlm. 1590, 234, 598.789.

${ }^{20}$ Yaitu; surat Al-An'am: 99 dan 141, surat An-Nahl: 11, surat AnNuur: 35, surat Al-Mu'minun: 20, surat 'Abasa: 29 dan surat At-Tin: 1

21 Zaghlul an-Najjar, Pembuktian Sains dalam Sunnah, terj. Zainal Abidin, dkk. (Jakarta: Azmah, 2006) hlm.137-140. 


\section{Pandangan Ahli mengenai Zaitun}

Menurut kutipan dari Prof Dr. Said Hammad, yakni dari Dr. Hasan Syamsi Pasha dalam bukunya, Zait Az-Zaitun Baina At-Thibb wa Al-Qur'an (Pohon Zaitun dalam Perspektif Medis dan Al-Qur'an) menyebut beberapa keistimewaan pohon zaitun yang penuh berkah itu. Beliau menuturkan, "Pohon zaitun ini memiliki keistimewaan umurnya yang panjang, meski akar pokoknya mati. Dahan-dahannya baru terbentuk di sekitar dasarnya yang pada akhirnya menumbuhkan pohon baru."22

4. Pengertian dan Asal-usul Zaitun

Dalam bahasa Arab, kata الزت diartikan sebagai minyak zaitun, dan kata زبتون memiliki arti buah zaitun. ${ }^{23}$ Sedangkan dalam Kamus Besar Bahasa Indonesia (KBBI), zaitun bermakna "Zat cair berlemak, biasanya kental, tidak larut dalam air, larut dalam eter dan alkohol, mudah terbakar, bergantung pada asalnya, dikelompokkan sebagai minyak nabati, hewani, atau mineral dan bergantung pada sifatnya pada pemanasan dapat dikelompokkan sebagai asiri atau tetap. ${ }^{24}$

Dunia ilmiah mengenal buah zaitun adalah pohon yang buahnya mengandung minyak. Pohon ini selalu hijau sepanjang tahun. Tinggi pohonnya kira-kira tiga meteran. Namun zaitun yang dibudidayakan bisa dijaga tingginya dengan pemangkasan. Tanaman ini termasuk tanaman kuat, mudah berakar dan bertunas. Tumbuhnya saling berlawanan. Daunnya berwarna hijau terang dan seolah-olah tumbuh berpasangan pada sisi kiri dan kanan. Buah zaitun yang masak ranum berwarna ungu kehitaman. Buahnya lunak dan berisi penuh cairan berbentuk lonjong atau membulat. Zaitun amat kaya dengan vitamin A, B1, B2, C, D, E, $\mathrm{K}$, dan zat besi.

Zaitun sangat istimewa dan merupakan pohon yang berumur panjang yang bisa mencapai 500 tahun hingga 1500 tahun. Minyak Zaitun merupakan sari minyak yang didapatkan dari buah zaitun. Terkadang sari tersebut digunakan sebagai

22 T. Malichah. "Zaitun dalam al-Qur'an” dalam Skripsi (Semarang: UIN Walisongo, 2016). hlm.16.

23 Ahmad Warson Munawir. Kamus Al-Munawwir Arab-Indonesia. (Yogyakarta: Pustaka Progresif,1997) hlm. 596.

${ }^{24}$ https://kbbi.web.id 
minuman, minyak untuk bahan masakan, dan beberapa kegunaan lainnya. Pohon zaitun adalah satu pohon tertua yang dikenal manusia sepanjang sejarah. Pohon zaitun disebut dalam Al-Qur'an dan As-Sunnah sebagai isyarat mengenai urgensi dan ketinggian nilai pohon yang dimuliakan oleh seluruh jajaran langit. Zaitun adalah sumber rezeki, kebaikan dan juga keberkahan. Sebagaimana Allah SWT mengisyaratkan kepada kita semua akan tingginya kedudukan zaitun. ${ }^{25}$

Sejarah zaitun sudah tercatat sejak zaman dahulu. Catatan sejarahnya berbaur dalam berbagai kisah, peperangan, perjanjian, perdagangan, peradaban, ilmu pengetahuan, dan pengobatan. Terbukti dahan zaitun dijadikan simbol yang menonjol dalam tradisi dan sejarah orang-orang Mesir Kuno. Tidak ada seorang pun tahu secara pasti siapakah orang yang pertama kali menggunakan minyak zaitun. Meskipun kebanyakan bukti-bukti sejarah menunjukkan bahwa Syiria adalah tempat pertama tumbuhnya zaitun. Bangsa Syiria telah menanam pohon zaitun sekitar 6.000 tahun sebelum bangsa Semit. Asal muasal pohon ini diperkirakan berasal dari kawasan Mediterania. Ada yang menyebut wilayah Syiria dan Palestina.

Ada juga yang menemukan jejak keberadaan zaitun di Afrika Timur sejak 500.000 tahun yang lalu. Selain Asia, Eropa, dan Afrika, dua benua lainnya tidak ketinggalan ikut membudidayakan pohon zaitun. Australia dan Amerika Serikat termasuk dua Negara yang ikut mengembangkan buah purba ini. Sehingga sekarang khusus di Amerika Serikat yakni California, adalah tempat pengembangan zaitun yang paling maju. Dan zaitun California merupakan zaitun yang berkualitas terbaik di dunia hingga saat ini. Sementara beberapa literatur sejarah lainnya menunjukkan bahwa negeri Palestina terkenal dengan zaitun dan telah mengekspornya ke Mesir Kuno. Pohon zaitun mulai masuk negeri Mesir dizaman bangsa Hyksos. yang menyerang Mesir sejak sekitar 1650 tahun sebelum Masehi, dan berkuasa di sana selama 100 tahun.

Pohon zaitun merupakan pohon tertua yang dikenal manusia sepanjang sejarah. Sejarah lain mengatakan Lembah Thur

25 T. Malichah. "Zaitun dalam al-Qur'an" dalam Skripsi (Semarang: UIN Walisongo, 2016). hlm.17. 
merupakan lembah suci tempat pohon zaitun ditemukan dan tempat terdekat dengan Jazirah Arab. Naungan yang dimaksudkan ada dalam Al-Qur'an. Penganugerahan zaitun sebagai pohon suci sepertinya memang bukan alasan. Negara-negara di Afrika dan Timur Tengah sudah sangat lazim membudidayakan pohon zaitun. Zaitun kerap hadir dalam menu makanan sehari-hari orang Barat. Dua bagian pokok yakni buah dan daunnya memberi berbagai manfaat pada kesehatan. Pohon zaitun memiliki keistimewaan, yakni tumbuh dibumi yang penuh berkah. Minyaknya bercahaya dan pohonnya rindang. Zaitun juga mempunyai usia yang sangat panjang. Maka, bukan hal yang aneh bila kita menemukan pohon zaitun yang berusia 600 tahun di Palestina. Satu pohon zaitun bisa menghasilkan 15 hingga $20 \mathrm{~kg}$ buah zaitun dalam satu tahun. Spanyol, Italia, Yunani, Turki, Tunisia, Portugal, Maroko, Suriah, Aljazair, Argentina, dan Prancis merupakan negara-negara yang dikenal sebagai penghasil minyak zaitun. ${ }^{26}$

5. Manfaat dan Penggunaan Minyak Zaitun di Masa Modern

Masyarakat modern zaman sekaramg ini tidak hanya menggunakan obat-obatan medis untuk konsumsi pengobatan ataupun untuk vitamin sehari-hari. Beberapa orang juga menggunakan obat herbal. Buah zaitun pada masa modern ini lebih sering ditemukan dalam bentuk sarinya, atau dalam bentuk minyak. Minyak zaitun sekarang ini sering digunakan sebagai minyak untuk perawatan wajah ataupun minyak untuk memasak, karena kandungan kolestrolnya yang tidak banyak. Selain itu, minyak zaitun juga digunakan sebagai media "diet" bagi beberapa orang yang memiliki kelebihan berat badan.

Pohon zaitun yang berwarna hijau ini tumbuh di kawasan Laut Tengah, namun sekarang ini sudah tersebar ke berbagai Negara, khususnya Asia dan Afrika. Pohon ini sudah dikenal sejak zaman peradaban kuno sebagai salah satu minyak terpenting. Pohon ni diproses menjadi minyak oleh hampir semua orang apabila menggunakannya.

26 T. Malichah. "Zaitun dalam al-Qur'an” dalam Skripsi (Semarang: UIN Walisongo, 2016). hlm.16-20. 
Riset menunjukkan bahwa kandungan asam lemak minyak zaitun sangat sedikit dan lemak yang dikandungnya itu bukan lemak yang mengenyangkan. Minyak ini mengandung nilai kesaehatan yang tinggi, karena kesterilannya dari zat-zat penyebab penyempitan dan penyumbatan pembuluh darah. Beberapa hasil penelitian dan percobaan membuktikan bahwa apabila mengonsumsi minyak zaitun secara terarur efektif mencegah tubuh dari berbagai penyakit, diantaranya, penyumbatan pembuluh darah coroner (jantung kororner), peningkatan kadar lemak berbahaya dalam darah, tekanan darah tinggi, kencing batu, dan beberapa jenis kanker seperti kanker payudara, rahim, dan kulit. ${ }^{27}$

Minyak zaitun mengandung vitamin E dan senyawa Polyphenolic Compounds yang dapat mencegah terjadinya oksidasi spontan lemak, senyawa ini juga melindungi tubuh dari bahaya Lipid Peroxides, dan bahaya lain dari zat-zat berbahaya.

Maka dari itu, mengkonsumsi minyak zaitun secara rutin dapat menurunkan kadar kolestrol dalam tubuh. Minyak ini juga digunakan untuk memasak, dan ditambahkan pada salad, memproduksi obat, cream, minyak rambut, dan sabun. Bahkan minyak ini juga digunakan sebagai tambahan supaya lampu menjadi lebih terang, khususnya di masjid besar seperti Masjid alAqsha.

Minyak ini juga memiliki manfaat non-medis, yaitu berfungsi sebagai lauk, pemberi cita rasa, dan penambah selera. Batang dari pohon zaitun juga bisa dijadikan siwak, yang mana merupakan siwak terbaik dalam hadis Nabi. ${ }^{28}$

\section{Madu}

1. Hadis Tentang Madu Takhrijnya

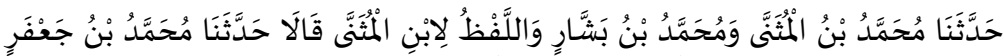

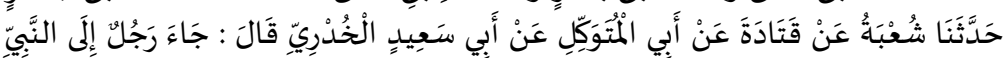

27 Zaghlul an-Najjar, Pembuktian Sains dalam Sunnah, terj. Zainal Abidin, dkk. (Jakarta: Azmah, 2006) hlm.137-140.

${ }^{28}$ Zaghlul an-Najjar, Pembuktian Sains dalam Sunnah, terj. Zainal Abidin, dkk. (Jakarta: Azmah, 2006) hlm.137-140. 


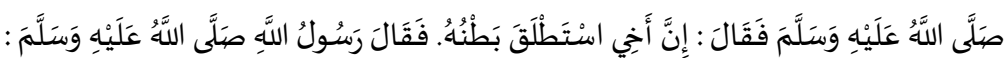

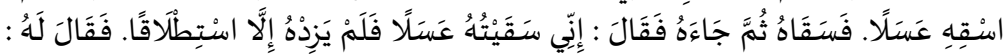

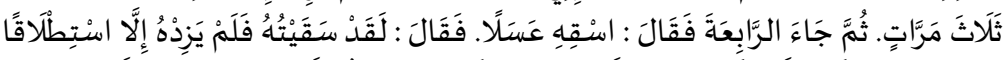

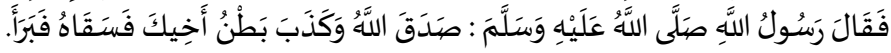

"Telah menceritakan kepada kami Muhammad kepada kami Muhammad bin Al Mutsanna dan Muhammad bin Basyar; Dan lafazh ini miliknya Ibnu Al-Mutsanna dia berkata; Telah menceritakan kepada kami Muhammad bin Ja'far; Telah menceritakan kepada kami Syu'bah dari Qatadah dari Abu AlMutawakkil dari abu Sa'id Al-Khudri dia berkata; "Seorang laki-laki datang kepada Rasulullah shallahu 'alaihi wasallam lalu dia berkata; 'Saudaraku sakit perut sehingga dia buang-buang air.' Rasulullah shallahu 'alaihi wasallam bersabda: 'Minumlah madu kepadanya!' Lalu diminumkan madu kepadanya. Kemudian dia datang lagi kepada Nabi shallahu 'alaihi wasallam lalu katanya: 'Telah kuminumkan madu kepadanya, tetapi sakitnya bertambah.' Nabi shallahu 'alaihi wasallam menyuruhnya pula meminumkan madu sampai berulang tiga kali. Dia datang untuk keempat kalinya, Nabi shallahu 'alaihi wasallam tetap menyuruhnya meminumkan madu. Kata orang itu; 'Aku telah meminumkannya, ya Rasulullah, namun sakitnya bertambah juga.' Rasulullah shallahu 'alaihi wasallam bersabda: 'Allah Maha Benar! Perut saudaramu itulah yang dusta.' Lalu diminumkannya pula madu dan sembuhlah dia" 29

Adapun takhrij dan kualitas sanad dari hadis diatas yaitu:

\begin{tabular}{|c|c|c|c|}
\hline 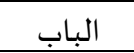 & 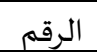 & الطرف & 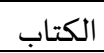 \\
\hline باب دواء & 5277 & 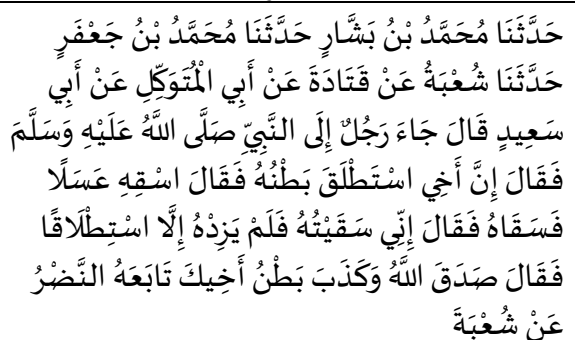 & البخرى صحيح \\
\hline باب ما جاء & 2008 & 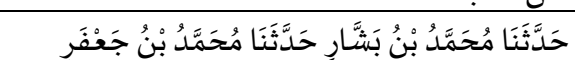 & متن \\
\hline
\end{tabular}

29 Imroatus Solihah, Madu sebagai Obat, (Yogyakarta: Fakultas Ushuluddin dan Pemikiran Islam, UIN Sunan Kalijaga, 2013), hlm. 45-46. 


\begin{tabular}{|c|c|c|c|}
\hline في التداوى & & 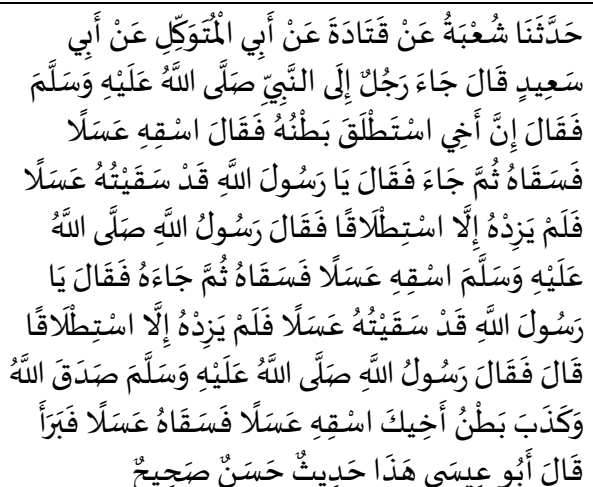 & الترمذي \\
\hline تسعيد البـ & 10719 & 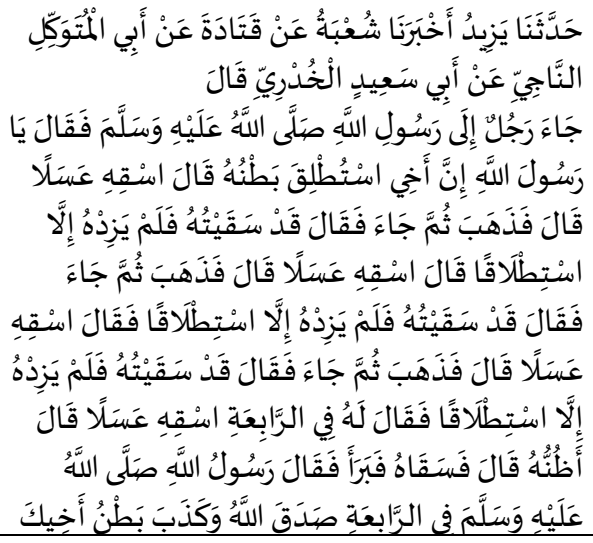 & أحمد مسند \\
\hline
\end{tabular}

Hadis tentang penggunaan madu sebagai pengobatan jika ditinjau dari sanadnya adalah:

a. Diriwayatkan oleh rawi yang 'adil, siqah, dhabit serta tidak ada celaan (jarh) sebagaimana tercantum dalam rawinya.

b. Mempunyai sanad muttasil dari mukharrij sampai Rasulullah (bersumber dari Nabi).

c. Tidak ditemukan adanya syadz (kejanggalan) maupun 'illat (cacat) dalam sanadnya, sebab adanya pendukung yang menguatkan.

Adapun dari aspek matannya, hadis ini bersifat otentik. Jika mengacu pada pendapat jumhur ulama' hadis, yang memberikan kriteria terhadap aspek matan dengan tidak mengandung syadz (kejanggalan) maupun 'illat (cacat) yang terangkum dalam hadis, tidak bertentangan dengan al-Qur'an, 
hadis, logika, ilmu pengetahuan maupun sejarah, maka hadis ini sudah memenuhi kriteria yang telah disebutkan. ${ }^{30}$

2. Syarah Hadis

(إنَّ عَرَِ بَطْنُهُ) lafazh 'ariba 'ain-nya di fathah dan ra'-nya di kasrah artinya perutnya rusak, sabda Nabi Saw (Allah Maha Benar dan perut saudaramu itulah yang dusta). Yang dimaksud firman Allah (يَخْرُجُ لِلنَّاس) yaitu madu. Ini merupakan penjelasan Nabi Saw bahwa sesungguhnya kata ganti dalam firman Allah (فِيْيَه

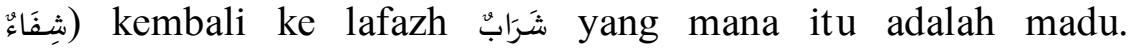
Penjelasan itu benar berdasarkan pendapat Ibnu Mas'ud, Ibnu Abbas, Hasan, Qatadah, dan selain mereka. Imam Mujahid berpendapat kata ganti itu kembali kepada al-Qur'an. Pendapat ini lemah; bertentangan dengan penjelasan hadis yang shohih ini. Sebagian ulama' berpendapat ayat itu khusus, artinya, penyembuh dari sebagian beberapa penyakit dan sebagian manusia.

Penyakit perut ini merupakan sebagian dari penyakit yang bisa disembuhkan dengan madu. Ayat itu (QS. An-Nahl: 69) tidak menjelaskan bahwa madu adalah obat dari semua penyakit, tetapi intruksi Nabi Saw sesungguhnya penyakit laki-laki ini hanya sebagian dari penyakit yang bisa disembuhkan dengan madu. ${ }^{31}$

3. Manfaat Madu Bagi Kesehatan

Manusia telah menggunakan madu untuk pengobatan, sejak zaman kuno. Madu telah disebutkan dalam literatur kerajaan-kerajaan kuno, seperti; Sumeria, Babilonia, Mesir, dan India. Kaum muslimin menggunakan madu sebagai nutrisi dan obat, sebagaimana disebutkan dalam al-Qur'an, “.... Di dalamnya terdapat obat yang menyembuhkan bagi manusia ....” (QS. AnNahl: 69). ${ }^{32}$

Para ahli sejarah menyebutkan bahwa Phytagoras hidup dalam usia lebih dari sembilan puluh tahun, makanan pokoknya sehari-hari terdiri dari roti dan madu. Diskusi tentang madu mendapat banyak perhatian dalam dunia kedokteran. Beberapa

30 Imroatus Solihah, Madu sebagai Obat, (Yogyakarta: Fakultas Ushuluddin dan Pemikiran Islam, UIN Sunan Kalijaga, 2013) hlm. 72.

${ }^{31}$ Maktabah Syamilah, Al Minhaj Syarh Shahih Muslim bin Hajjaj.

${ }^{32}$ Said Hammad, 99 Resep sehat dengan Madu, (Solo: Aqwamedika, 2012), hlm. 44. 
artikel yang dipublikasikan di majalah-majalah kedokteran yang terpercaya, antara lain: Bakteri Tidak Mampu Melawan Madu, Penggunaan Madu sebagai Antikula, Madu dan Luka Bakar, Madu Kaya Kandungan Antioksidan, Madu dan Kesehatan Mulut, Madu dan Pengobatan Infeksi Selaput Lendir Akibat Radiasi, Antara Madu dengan Infeksi Lambung (Maagh) dan Tukak Lambung, Madu Mencegah Terjadinya Radang Usus Besar, Madu dan Kulit Kepala, Madu dan Pengobatan Kencing Manis. ${ }^{33}$

Allah sudah menyiapkan apa yang dinamakan "klaikoprotein" yang sangat penting di dalam madu karena gunanya ada tiga macam, antara lain:

a. Membentuk pembantu-pembantu organ tubuh atau enzimenzim.

b. Menyusun macam-macam hormon.

c. Membentuk jasad-jasad pelawan bibit penyakit. ${ }^{34}$

Madu juga bisa dimanfaatkan untuk kecantikan. Pada tahun 1835 di London, tersiar kabar bahwa madu dapat memperindah dan melindungi kulit, mencegah dan mengobatinya dari pecah-pecah, serta sangat ampuh bagi kulit tangan dan bibir. Pada tahun 1972, Charles Reflon mengumumkan bahwa madu lebah dicampur susu murni dapat menghasilkan kecantikan $100 \%$. Madu dan susu memberikan kesuburan dan kecantikan pada kulit karena mengandung susunan alami yang penting. Oleh karena itu, madu dimasukkan dalam salah satu komposisi bedak dan alat-alat kecantikan. ${ }^{35}$

4. Kontekstualisasi Hadis Tentang Madu sebagai Obat

Berdasarkan redaksi hadis yang telah disebutkan di atas, dapat diketahui bahwa penyakit sudah ada sejak zaman Nabi. Pada saat itu, Pola hidup pada zaman Nabi dan sekarang berbeda, dari segi makanan yang dikonsumsi maupun lingkungan. Pada zaman Nabi, makanan yang dikonsumsi masih alami dan

33 Muhammad Albani, Keajaiban Thibbun Nabawi, (Surakarta: AlQowam, 2012), hlm. 282-287.

34 Lalu Ibrahim M. Thayyib, Keajaiban Sains Islam, (Yogyakarta: Pinus Book Publisher), hlm. 269.

35 Abdul Basith Muhammad Sayyid, Rahasia Kesehatan Nabi, (Solo: Tiga Serangkai, 2004), hlm. 160. 
sederhana, jadi penyakit yang ditimbulkan juga tidak kompleks seperti sekarang.

Hadis tentang madu yang digunakan sebagai obat diriwayatkan sekitar 14 abad yang lalu. Jarak waktu antara periwayatan hadis dengan sekarang terpaut jauh. Teknologi pun berkembang begitu pesat. Berkembangnya teknologi juga berdampak pada makanan. Dewasa ini, makanan banyak yang dikonsumsi oleh masyarakat pada umumnya adalah makanan instan yang mengandung unsur kimia yang berbahaya bagi kesehatan tubuh, seperti zat pewarna dan pengawet makanan. Beragam penyakit pun bermunculan disebabkan makanan instan, dari penyakit yang ringan hingga yang akut. ${ }^{36}$

Dalam syarah an-Nawawi tentang hadis madu yang diriwayatkan oleh Imam Muslim dijelaskan bahwa pada QS. AnNahl: 69 tidak menjelaskan bahwa madu adalah obat dari semua penyakit, tetapi intruksi Nabi Saw pada hadis tersebut sesungguhnya penyakit laki-laki itu hanya sebagian dari penyakit yang bisa disembuhkan dengan madu. Menimbang juga dari semakin modernnya gaya hidup masyarakat dan makanan siap saji yang dikonsumsi, maka tidak menutup kemungkinan bagi orang yang sakit untuk menggunakan alternatif lain sebagai usaha agar bisa sembuh. Nabi juga menawarkan banyak alternatif lain, seperti bekam dan habbatus sauda'.

\section{E. Kesimpulan}

Terdapat banyak sekali manfaat yang terkandung di dalam habbatus sauda', zaitun dan madu. Penelitian kedokteran modern juga telah membuktikan akan khasiat yang terkandung di dalamnya. Hal ini mampu menguatkan akan hadis Nabi SAW yang berbicara tentang obat-obatan yang mampu menyembuhkan berbagai penyakit. Adapun manfaat dari habbatus sauda' yaitu mampu menyembuhkan perut kembung, menghilangkan penyakit kembung, nyeri dada, batuk, sesak nafas, mual, edema (busung air), asites, sakit kuning, penyakit pada limpa dan mampu meningkatkan syahwat. Ada juga manfaat dari zaitun yaitu zaitun

36 Imroatus Solihah, Madu sebagai Obat, (Yogyakarta: Fakultas Ushuluddin dan Pemikiran Islam, UIN Sunan Kalijaga, 2013) hlm. 89. 
mengandung vitamin E dan senyawa Polyphenolic Compounds yang dapat mencegah terjadinya oksidasi spontan lemak, senyawa ini juga melindungi tubuh dari bahaya Lipid Peroxides, dan bahaya lain dari zat-zat berbahaya, selain itu juga dapat menurunkan kadar kolestrol dalam tubuh. Minyak ini juga digunakan untuk memasak, dan ditambahkan pada salad, memproduksi obat, cream, minyak rambut, dan sabun. Adapun manfaat madu diantaranya membentuk pembantu-pembantu organ tubuh atau enzim-enzim, menyusun macam-macam hormon, membentuk jasad-jasad pelawan bibit penyakit dan juga madu digunakan dalam hal kecantikan yaitu bahwa madu dapat memperindah dan melindungi kulit, mencegah dan mengobatinya dari pecah-pecah, serta sangat ampuh bagi kulit tangan dan bibir.

\section{DAFTAR PUSTAKA}

Abdullah Umar Bamusa dan Yusuf Abu al-Hujaj. 2011. Sembuh dan Sehat dengan Habbatus.

Abdurrahman, Asjmuni. 2012. Manhaj Tarjih Muhammadiyah. Yogyakarta. Pustaka Pelajar.

Ali, Nizar. 2008. Hadis Versus Sains. Yogyakarta: Teras.

Albani, Muhammad. 2012. Keajaiban Thibbun Nabawi. Surakarta: Al-Qowam.

Ash-Shiddieqy, TM Hasbi. 2009. Sejarah dan Pengantar Ilmu Hadis. Semarang. Pustaka Rizki Putra.

Hammad, Said. 2012. 99 Resep sehat dengan Madu. Solo: Aqwamedika.

Malichah, T. 2016. "Zaitun dalam al-Qur'an" dalam Skripsi, Semarang: UIN Walisongo

Munawir, Ahmad Warson. 1997.Kamus Al-Munawwir ArabIndonesia. Yogyakarta: Pustaka Progresif.

Sauda'. terj. Umar Mujtahid. Solo: Aqwamedia.

Sayyid, Abdul Basith Muhammad. 2004. Rahasia Kesehatan Nabi. Solo: Tiga Serangkai. 
Alfandi Ilham Safarsyah

Solihah, Imroatus. 2013. Madu sebagai Obat. Yogyakarta: Fakultas Ushuluddin dan Pemikiran Islam, UIN Sunan Kalijaga.

Thayyib, Lalu Ibrahim M. Keajaiban Sains Islam. Yogyakarta: Pinus Book Publisher.

Zaghlul an-Najjar. 2006. Pembuktian Sains dalam Sunnah, terj. Zainal Abidin, dkk. Jakarta: Azmah.

\section{Sumber Lain:}

CD Lidwa Ensiklopedi Hadis 9 Imam

CD Mausu'uatul Hadits an-Nabawiyah

Maktabah Syamilah

https://kbbi.web.id 